Jens Kr. Andersen

\title{
Historie eller analogi?
}

\author{
Om Erik A. Nielsens disputats Holbergs komik (Kbh. \\ 1984)
}

\begin{abstract}
Nedenstående udgjorde grundlaget for min opposition ex auditorio ved forsvarshandlingen på Københavns Universitet den 31. maj 1985. I forhold til det oprindelige manuskript har jeg kun foretaget sădanne ændringer, som det ændrede medium gør naturligt. Derimod er der grund til at gøre opmærksom på, at den tilmålte tid ikke tillod mig at fremføre den kritik, som indeholdes $\mathrm{i}$ afsnit III her.
\end{abstract}

Afh. behandler Holbergs »komiske forfatterskab « fra perioden 17191726 - Peder Paars, satirerne (»skæmtedigtene«), komedierne og $\mathrm{Me}$ tamorphosis - som et forkortet udtryk for en generel civilisationshistorisk udvikling bort fra organiske og kosmiske sammenhænge og frem mod intellektets amputerende dominans.

For studiet af Holbergs tekster i deres kultur- og socialhistoriske sammenhæng forekommer især to partier $i$ afh. interessante og langthen overbevisende. For det forste de væsentlige dele af Peder Paarsanalysen, der forbinder den klassicistiske imitationspoetik bagud til exemplum-pædagogiken, hvorved rækkevidden af Holbergs parodi øges betydeligt. For det andet analysen af »Mascarade«, der dristigt, men ikke ueffent forbindes med oldtidens saturnalier. Det er derfor naturligt at starte med et par bemærkninger netop til disse to analyser.

Når der i afh. lægges så betydelig vægt på at beskrive det brud med og opbrud fra det 17. årh.s klassicisme og humanisme, Holberg foretager med Peder Paars, og når afh. afgrænser denne reaktion med Metamorphosis (1726), er det overraskende, at afh. ikke inddrager eller blot nævner Vilh. Andersens Tider og Typer, der i bindet Erasmus II (1909) bringer en udførlig beskrivelse af netop disse forhold, og hvis hovedpointe (og et par bipointer) falder sammen med Erik A. Nielsens ${ }^{1}$ ). Dennes bibliografi, hvis motto ganske vist er Holbergs formaning om ikke at lade hjernen sløves af for megen læsning, rum- 
mer end ikke Vilh. Andersens navn.

Med hensyn til »Mascarade« må betænkelighederne især gå på, at netop denne komedie bliver den, hvoraf der gennemføres en egentlig analyse. Når »Mascarade" (i overskrift) betegnes som »Komediens arketype« (p. 208), betyder det ikke, at den er arketype i Holbergs komedieproduktion, men at den er genrologisk ærke-typisk. Smst. hedder det således: "I én forstand er den ikke det, man ville kalde en typisk holbergkomedie«; i hvilken forstand den så evt. er det, får man ikke at vide. Dens manglende repræsentativitet for Holbergs komedieforfatterskab fremgår af den klassifikation af komedierne, der (p. 236-238) foretages på grundlag af forskellige placeringer og forskellige instansers styring af anagnorisis, Aristoteles' betegnelse for den dramatiske gen- eller snarere erkendelse. Her hedder det meget oprigtigt om »Mascarade«, at den »som paradigme står temmelig isoleret i Holbergs komedieværk«, og i gruppen af de såkaldte "forsynskomedier« får den da også kun selskab af »Kilde-Reysen« og "Diderich Menschen-Skræk«. (Erkendelsesværdien af denne klassifikation begrænses i øvrigt af, at mens der af 26 komedier således rubriceres 3 som »forsynskomedier og desuden 3-4 som »tilfældighedskomedier «, anbringes 15-17 titler under kategorien »intrigantkomedier« og de øvrige 2-6 i en »restgruppe«. Men tilbage til placeringen af »Mascarade«:) Undervejs $\mathrm{i}$ analysen hedder det: »En vigtig erkendelsesgevinst ved at betone den kultlignende tredeling $i$ komediens mythos består deri, at den menneskelige skæbne synes at kunne forløbe analogt med naturlige og kosmiske rytmer« (p. 213). Det kan sammenholdes med udtalelsen p. 217, hvor det slås fast, at Holberg "stritter [...] kraftigt imod den komiske rytmes dybestliggende egenskaber «. Holberg vil øjensynlig ikke selv vide af disse kultiske, naturlige og kosmiske rytmer. Problemet i forbindelse med »Mascarade«-analysen $\mathrm{i}$ forfatterskabssammenhæng bliver derfor, at de mønstre, denne analyse påviser, synes at være både atypiske $i$ forhold til forfatterskabet og fremmede for forfatterens forestillingsverden, begge dele $\mathrm{i}$ henhold til analysatorens egen indrømmelse.

\section{II}

Vi skal herefter forsøge en mere principiel bestemmelse af Holbergs komik som litteraturhistorisk videnskab. Man kunne indvende, at en sådan accentuering af afh.s historiske aspekter måske stred mod forf.s erklæring om, at de fremanalyserede udviklingstrin i forfatterskabet 
»snarere [er] mytiske end historiske« (p. 384). På den anden side bestemmes myten i denne forbindelse som »historien i pointeret form«, og afh. lægger i det hele taget afgørende vægt på forhold til forbilleder, kronologisk rækkefølge af værker etc., ligesom i hvert fald de fem første af de seks teser (p. 40-43) er af erklæret historisk karakter.

Afh. rummer studier inden for tre litteraturvidenskabelige discipliner: 1. tekstanalyse, 2. genrehistorie og 3. åndshistorie. Vi vil forsøge at vise, at forf. på alle tre områder har stillet sin opgave sådan, at han har frigjort sig fra væsentlige historiske forpligtelser, og desuden demonstrere konsekvensen af hver disciplins manglende historiske forpligtelse for en konkret tekstanalyse. Som eksempel er valgt analysen af »Erasmus Montanus« (p. 297-305), men med samme resultat kunne også have været valgt f.eks. analysen af »Jeppe på Bierget« (p. 319-325). Over for »Erasmus Montanus« synes forf. at være nær ved explicit at opgive en egentlig analyse (se pp. $301 \mathrm{~m}, 303 \mathrm{n}, 305 \mathrm{~m}$ ), og i hvert fald m.h.t. denne komedies slutning, der omtales som "grimasse« (pp. 283, 300) og »dissonans « (p. 301), ses pointen just i uopløseligheden. Det vil være min påstand, at en sådan analytisk defaitisme bl.a. er en følge af en upræcis historik.

Først tekstanalysen. Et iøjnefaldende og konsekvensrigt træk ved afh.s tekstanalyse er praktiseringen af den hermeneutiske metode, der fremlægges i indledningen: »Den genskabende forståelse er en uundværlig bestanddel af enhver hermeneutisk aktivitet, og det er den fortolkede tekst selv, der er prøven på aktivitetens videnskabelige holdbarhed. I jo højere grad teksten genopstår som konsekvent og sammenhængende størrelse under fortolkerens fremstilling af den, jo præcisere har den hermeneutiske genskabelse af den været. Og man kan tilføje: jo dybere er tekstens historiske egenart klargjort [...]. Men interpretationens afgørende teoretiske forudsætning er den, at man ikke kan navngive eller begrebsliggøre et fortidigt fænomen, før man har ladet det virke på sig og derved så at sige ladet det give sin egenarts hemmeligheder fra sig. Iagttaget på denne måde er fortiden noget, der er under stadig tilblivelse i nutidige fortolkere« (p. 35). Man kan påkalde sig det fine begreb »hermeneutik « og Gadamers tykke, tyske bog ${ }^{2}$ så meget man vil; tilbage som konsekvens står en opgivelse af bestrebelsen på at forstå en litterer text på grundlag af dens egen tid. Forf. forsikrer, at denne "genskabende forståelse [...] ikke [er] den subjektive vilkårlighed, man ofte maner frem som et skræmmebillede« (ibid.), men afh.s egne analyser er ikke alle lige egnede til at holde skræmmebilledet på tilbørlig afstand. Metodens svaghed viser sig ofte som sorgløshed m.h.t. den historiske bestemmelse af det pub- 
likum, der indgår i det »hermeneutiske« møde med Holbergs tekster. Her holdes sam- og eftertid ikke altid ude fra hinanden, og Holbergtidens forestillinger blandes med en moderne læsers.

Det viser sig måske tydeligst $\mathrm{i}$ understregningen af komediernes komik på bekostning af deres moral. Konflikten mellem disse to størrelser og udpegelsen af komikken som det »egentlige« var pointen $\mathrm{i}$ Jens Kruuses Holbergs maske (1964), hvortil Erik A. Nielsens tilsvarende bestemmelser forholder sig som en modificeret variant. Et par af disse bestemmelser fortjener at citeres og kommenteres: "[...] der har eksisteret en skjult og lidenskabelig forbindelse mellem publikum og kunstnere, som foregik i det ordløse, mens der ovenover befandt sig et dæklag af acceptable og tillidsvækkende erklæringer [...]. I Holbergs digtning foreligger denne konflikt i fuldt flor « (p. 309). Bortset fra de vanskeligheder, det skjulte og ordløse vel altid vil volde en tekstanalytiker, er problemet her, hvilket publikum - hvilken tids publikum - der kan tænkes at etablere en sådan umoralsk og underjordisk forbindelse med autor. Straks efter tilspidses problemet yderligere, idet Holberg med sin hyppigt erklærede moralske intention siges at "foretage en pragmatisering af hele komediens katharsis, som kun er en meget utilstrækkelig opsamling af de faktiske virkninger i hans komedier « (p. 310). De faktiske virkninger på hvem? Denne falske éntydighed bruges derpå argumentatorisk: »Ingen tilskuer kan være i tvivl om [...] « (ibid.). Én tilskuer har fornemmet følgende: "Hvor ubehageligt det end er at tænke på, så er det ikke desto mindre ham [i.e. stykkets moralist, »forfatterens talerør«], der tilsyneladende er fremtidens mand i komedierne. Det er ham, der er komediens moralske pointe, men han er det, især hos Holberg, på en så uudholdelig måde, at komedierne ret ofte mod deres hensigt (måske) overbeviser om, hvor utroligt meget sjovere det er at være umoralsk« (p. 278, jvf. p. 285). Hvor nær denne slemme amoralist står afh.s forf. bør man ikke gisne om, men vi ved heller intet om, hvorvidt Holberg-tiden delte hans ubehag ved moralen.

Skønt den "rene« komiks overherredømme gang på gang slås fast (se fx. p. 325), opererer afh. alligevel med begrebet "straffelatter", der vel må ligge nær realisationen af Holbergs erklærede intention: at moralisere med komikken som middel. Det samme gør følgende indrømmelse: "Det er i virkeligheden en meget gnaven og økonomisk kyndig bevidsthed, der her bliver placeret som komediens styrende og latterskabende [!] kraft « (p. 287) - og ligeledes fx. bestemmelsen af »Barselsstuen«s handlingsgang som »nærmest en eksemplificerende argumentation« (p. 288). I kapitlerne p. 284-92 dominerer i det hele taget den historiske, Holbergske moralisme, men da denne al- 
drig samlet og principielt afvejes og afgrænses i forhold til den moderne, komik-centrerede amoralisme, kommer selve afh.s grundopfattelse af komedierne til at fluktuere.

Hvilken virkning får det nu for analysen af »Erasmus Montanus«, at den ikke er forpligtet på det 18. århundredes moraliserende og pædagogiserende hensigter? I stikordsform kan komediens væsentligste modsætninger ifølge Erik A. Nielsens analyse skrives:

$$
\frac{\text { bondesamfund }}{\text { akademisk karrière }} \simeq \frac{\text { [virkelighedsnær praxis] }}{\text { hjemløs teori }} \simeq \frac{\text { erotik (kærlighed) }}{\text { tanke (fornuft) }}
$$

Kun temabestemmelsen i [] findes ikke ordret på siderne 298, 300 og 301 , men indkatalyseringen af den turde være berettiget som resumé af analysens formuleringer p. 298 um-n og p. 302 um-n. - Vi vil påstå, at denne bestemmelse af komediens tematik er misvisende $\mathrm{i}$ forhold til texten, og at misvisningen skyldes et moderne blik på den gamle text. Tilstedeværelsen af den moderne bevidsthed lader sig let dokumentere (fremhævelserne i de følgende citater er vore): I forbindelse med lokalbefolkningens stadige påberåbelse af consensus mindes vi om, at "Domsmandsinstitutionen såvel som det moderne demokrati hviler på denne forestilling om det velmotiverede lægmandsskøn« (p. 304), Holberg er indfanget af »den moderne akademisme« (p. 301), hvis bondedyrkelse udtrykker »en lidt nostalgisk bevidsthed " (ibid.); dialogen og konflikten mellem de to sfærer "tematiserer en radikal spænding i moderne menneskers erfaringsverden « (p. 305) og gengiver det "moderne samfunds stadige sammenstød mellem snusfornuften og ekspertudsagnet « (p. 304). Først senere tiders intellektuelle typer fik problemer med deres tabte naivitet, deres fjernelse fra et »autentisk« milieu, deres krops- og instinktfornægtelse etc. etc. Disse moderne indlæsninger ville kunne gælde for mulige læsemåder, hvis de passede på texten, men det gør de ikke. Holbergs lære i »Erasmus Montanus« er nemlig netop, at den akademiske virksomhed ikke er adskilt fra virkelighedsnær praxis (eller erotik), og at akademikeren varetager disse områder fuldt så godt som bonden; det er ikke mellem disse socialgrupper eller milieuer som sådanne, komedien trækker grænser. Til understregning heraf har Holberg indført løjtnanten, som forf. da også under udnyttelsen af den ahistoriske whermeneutiks« subjektivisme lyser grundigt til dørs: "Som deus-ex-machina har løjtnanten i denne ironisk-intellektuelle komedie såre lidt at trække på til den konfliktløsning, der skal sikre komediens lykke. Mens komediens første fire akter er noget af det mest gnistrende og tætte, Holberg har sat på scenen, er femteakten dum og mekanisk, som om 
han har måttet give op over for løsningen af sit skisma« (p. 300). Løjtnantens figur kan meget vel forekomme moderne læsere/tilskuere kedsommelig, "forkert «, udramatisk, men han er der altså - og synes i texten at være tillagt nogen betydning. Alliancen mellem løjtnanten og Erasmus' broder Jacob udgør den positive pol i komediens værdiunivers. Hvad de to er enige om contra de værdier, Erasmus repræsenterer - det udgør komediens tematiske hovedmodsætning. Den kan bringes på begreber gennem en præcisering af bestemmelsen $\mathrm{i}$ analysens forste afsnit (p. 298, inden bonde-akademiker-modsætningen trækker den skæv). Her siges den basale modsætning at bestå mellem "to stridende erfaringsformer«, "tankeformernes sammenstød«. Jeg vil foreslå, at man kalder modsætningen instrumental vs. formal viden. Af Jacob og løjtnanten skal Erasmus lære, at viden skal tjene et socialt formål, ikke være mål i sig selv. Som man kan forvisse sig om andetsteds ${ }^{3}$ hos Holberg, er bondedrengen Jacobs agerdyrkning og den gamle academicus løjtnantens moralfilosofi henholdsvis "fornødne« og »nyttige« studier ${ }^{4}$.

Dernæst et par bemærkninger om afh.s genrehistoriske aspekter. Aristoteles har muligvis skrevet en bog om komedien. Hvis han har, er den gået tabt, og det eneste, der er bevaret til støtte for ideen, er en side med stikord, der bærer navnet "Tractatus Coislinianus«, hvis overlevering er sen, og hvis proveniens er tvivlsom, og som ikke kan gøre noget krav på litteraturteoretisk interesse ${ }^{5}$. Som hans Poetik nu foreligger for os, handler den om tragedien, et forhold, Erik A. Nielsen allerede udtrykker vel positivt, når han siger, at den »jo kun indirekte handler om komedien« (p. 187). Derfor - fortsætter han kan "mit komediebegreb kun indirekte [...] stå på Aristoteles' autoritet, men [må] i stedet [...] stå på yngre forskeres og min egen “ (ibid.). Det er et spørgsmål, om disse autoriteter ikke overvurderes, når der opstilles så detaillerede formodninger som denne: "[...] det er tankemæssigt nærliggende at forestille sig, at Aristoteles har måttet konstatere, at der i komedien kan foreligge en art rivalitet imellem den følgerigtige komposition og den vitssøgende« (p. 201). Når en teori om tragedier skal anvendes på komedier - endda klassicistiske, genrefaste sådanne - må begreberne "strækkes«; forfatteren anvender selv flere steder dette udtryk om sin fremgangsmåde (pp. 19, 228). Også to andre af forfatterens hjemmelsmænd, Hegel og Fergusson, må se deres begreber anvendt på andre genrer end dem, de har hævdet deres gyldighed for (pp. 84, 197, 207f.).

I stedet for at basere analysen af Holbergs komedier på Aristoteles' m.fl.s opfattelse af tragedien, kunne man interessere sig for, hvilken opfattelse af komedien, Holberg selv arbejdede ud fra. Vi skal ophol- 
de os nogle øjeblikke ved dette spørgsmål i almindelighed og i særdeleshed ved spørgsmålet om, hvilken betydning han tillagde komediens slutning. Holberg var ikke generøs med genretekniske erklæringer, og det må derfor undre lidt, at Erik A. Nielsen, der lægger den afgørende vægt på komediernes form (til forskel fra deres ideologiske indhold), ikke omtaler i hvert fald ét formelt credo, som Holberg fremfører. Jeg tænker her på det krav til en komedie, at den skal indeholde "3 Parter, nemlig protasis, epitasis og catastrophe« (ep. 441 ${ }^{6}$ ). Disse termer er ikke aristoteliske, og det kunne jo nok være værd at vide, hvor Holberg så har dem fra. Det er et af de uhyre få tilfælde, hvor man i Billeskov Jansens kommentar søger forgæves efter kilden? Den kan imidlertid med stor sandsynlighed identificeres som den romerske grammatiker Aelius Donatus' afhandling om komedien ${ }^{8}$, og sammesteds defineres komedier ved deres lykkelige slutninger, "laeti (...) exitus actionum «". Holberg tilslutter sig også Donat på dette afgørende punkt: I ep. 511a benytter han udtrykket »endes som en Comoedie « ${ }^{10}$ på en måde, der bekræfter forestillingen om den poetisk retfærdige slutning som et genrekrav.

Forfatteren nævner et par steder dette genretræk (pp. 200, 312), men da det ikke indbygges i en fundamental genreteori, slår det ikke igennem i analyserne, således heller ikke i den af »Erasmus Montanus«. Men her opstår så det problem, at afh.s bestemmelser af komediens slutning som »en grotesk grimasse« (p. 300, jvf. p. 283) ikke lader sig opretholde, hvis man tager Holbergs eget genrebegreb alvorligt. Og det er der al mulig grund til at gøre. Genreangivelsen »Comoedie« står i undertitlen og udgør således en del af texten. Det er en læseanvisning, der - historisk tydet - pålægger læseren at opfatte slutningen som retfærdighedens sejr. En analyse, der afviser femteaktens moralske udsagn, fordi den vurderes som »dum og mekanisk « (p. 300) er i direkte strid med Holbergs genrebegreb. Snarere bør man ved opstilling af det ideologiske regnskab begynde bagfra og ræsonnere: Fordi løjtnanten og hans synspunkter sejrer i komedien, fortjener de åbenbart at gøre det, og han er derfor berettiget til at bruge autoritetens midler. Hans »bondefangermetoder" er netop ikke "ganske modstridende med hans tanker«, sådan som afh. hævder (p. 300) - hans list og håndfasthed befordrer blot effektivt stykkets positive værdier.

Som andshistoriker fremlægger forfatteren sit program $\mathrm{i}$ indledningen. Efter nogle bemærkninger om embryonale træk af modernitet hos Holberg hedder det: »Jeg har i min afhandling forsøgt at tage konsekvensen af denne overvejelse ved så at sige at fortolke Holberg fremad imod vores egen tid. Det viser sig i praksis ved, at jeg på 
mange steder forsøger at placere ham i store tematiske sammenhænge, der går igennem kunst og kulturliv helt op til vore dage. $\mathrm{Og}$ ofte har jeg anvendt formuleringer og synspunkter, som senere tiders kunstnere har fremført uden mindste tanke på Holberg « (p. 38). Som ved det »hermeneutiske « program for tekstanalysen expliciteres den overhængende fare, idet der fortsættes: »Det er klart, at man her løber risikoen for at benytte en anakronistisk og uvidenskabelig fremgangsmåde [...] (p. 38f.). Det argument, hvormed forfatteren afviser denne risiko, er bemærkelsesværdigt; den påfølgende sætning lyder: "[...] men på den anden side er selv vores forestilling om historisk tænkning og videnskabelig dokumentation $\mathrm{i}$ alt væsentligt blevet til efter Holbergs værk, uden at vi af den grund kalder dem anakronistiske, når de anvendes på det« (p. 39). Altså: At vi ikke regner det for anakronistisk at benytte moderne metoder på aldre textmateriale, skulle give litteraturforskeren større frihed til at etablere åndshistoriske forbindelser mellem aldre og yngre tekstmateriale. At denne frihed faktisk er total, og forbindelserne altså kun behøver at legitimeres som associationer, fremgår af den følgende eksempelvise udpegelse af »forfatterskaber som Nietzsches og Ibsens, måske allerede Byrons og Kierkegaards « (p. 40) med forsikringen: »(...) det kommer ikke forståelsen af Holbergs forfatterskab til skade, når han bliver mødt med en bevidsthedsform, der for nutidsmennesker bl.a. er formuleret i forfatterskaber som de næunte« (ibid.). En bevidsthedsform, der skulle defineres ved kompagniet Nietzsche-Ibsen-Byron-Kierkegaard, måtte allerede have skizofrenien som en nærliggende mulighed, så man kan allerede her på side 40 frygte for konsekvenserne af citatets »bl.a.«. Frygten bliver ikke mindre, når bl.a. Hegel, Karen Blixen, Adorno og Per Højholt join'er selskabet.

Det omfang og generalisationsniveau, de indvarslede »store tematiske sammenhænge kan antage, fremgår af følgende to eksempler: »En af de helt afgørende begivenheder i den europæiske ånds udvikling udgøres af den over flere tusinde år udstrakte foregang, at de menneskelige forstandsevner og den menneskelige vilje trænger ind $i$ det mytiske og tilegner sig det som sit eget væsen« (p. 76). Og: "Set fra en bestemt synsvinkel handler Europas kulturhistorie om at finde måder at omgås det komiske på, måder at indkapsle det på» (p. 27). At et udsagn som det sidste tenderer mod at blive intetsigende fremgår af de mulige kommutationer: "Set fra en bestemt anden, tredje og fjerde synsvinkel handler Europas kulturhistorie om at finde måder at omgås det tragiske, det erotiske, det socialt subversive på, måder at indkapsle det på«.

De »store tematiske sammenhænge« bliver hyppigt mødested for 
åndshistoriske, genrehistoriske og samfundshistoriske forløb og udviklingstendenser. I en række tilfælde synes de forfægtede sammenhænge at bygge på et for spinkelt og diskutabelt grundlag, som når den i det 18. årh. uhyre udbredte teknik: mærkværdiggørelse gøres til et særligt manieristisk træk (p. 146). I andre tilfælde taber de i overbevisningskraft, når de udsættes for en (muligvis enfoldig) empirisk efterprøvning. Om satiregenrens sociale betingethed hedder det f.eks.: »Satiren synes at være en litterær form, der indfinder sig på tidspunkter, hvor samfundslivet befinder sig i en kritisk tilstand, fordi en masse mennesker, måske en hel samfundsklasse presser på for at vinde en plads med agtelse og indflydelse. Satiren er da med til at levere den grelle oplysning af disse mennesker, der er på vej op i lyset « (p. 118). I Danmark før 1800 blomstrer satiren i reformationstiden, i sidste halvdel af det 17. århundrede (med Lauremberg og fremfor alle Jacob Worm), omkring 1700 (med Helt, Reenberg og Sorterup), i 1720'rne (med Holberg, Falster og Horn) og i 1790'erne (med Abrahamson, P. A. Heiberg og Malthe Conrad Bruun). Men passer karakteristikken af den korresponderende samfundstilstand i virkeligheden ikke kun på det sidste tidsrum?

En åndshistorisk undersøgelse, der så ubesværet når frem til udsagn af så abstrakt karakter, mister let forbindelsen til den enkelte litterære text, der skulle være dens basis. Lad os vende tilbage til analysen af »Erasmus Montanus«. Med sigte på Erasmus og Jeronimus skriver forfatteren: „Fortolkningsproblemet, man står over for med denne komedie, beror på, at de begge har ret« (p. 303). Thi Erasmus er skør, og Jorden er rund. Det sidste må medgives af »[...] alle, der respekterer sand videnskabelig erkendelse [...] « (ibid.). Når vi i modsætning hertil argumenterede for, at Erasmus i komedien har udelt uret, kan det bekræftes af en textnær åndshistorisk undersøgelse. For Erasmus' forfægtelse af Jordens form, der i texten sammenkædes med hans forfægtelse af det copernicanske verdensbillede, har intet med sand videnskabelig erkendelse at gøre. Erasmus stræber udelukkende efter selvpromotion og beundring, men dertil kommer, at hans arrogant gentagne "Ingen lærde Folk tviler meer derom« (III, 5, jvf. III, 2 og V,5) i forbindelse med spørgsmålet om verdensbillederne var direkte forkert på komediens affattelsestidspunkt $\mathrm{i}$ 1723, og først kunne udtales med føje efter udgivelsen af Horrebows Copernicus Triumphans fire år senere. Det er altså en umoden duks hos professor Horrebow, der her spiller op. Denne duks har tilegnet sig begyndelsesgrundene $i$ en samling universitetsfag og -discipliner, der fra et moderne synspunkt er et sært pêle-mêle af skolastiske reminiscenser og moderne naturvidenskab, men som historisk havde to ting 
til fælles: De havde formalistisk og deduktiv karakter, og Holberg betragtede dem (i hvert fald på dette tidspunkt) som uvesentlige: asociale, unyttige og verdensfjerne. Om disse forhold kan der læses mere udførligt i Ebbe Spang-Hanssens fortrinlige bog Erasmus Montanus og naturvidenskaben (1965), som forfatteren anfører i bibliografien, men ikke inddrager $\mathrm{i}$ analysen. $\mathrm{Og}$ en inddragelse af Spang-Hanssens resultater måtte have forhindret hans nedslående renoncering på at løse problemet om komediens tilsyneladende ambivalens, for det problem har faktisk været tilfredsstillende løst i nu 20 år.

\section{III}

Vi har altså forsøgt at påvise, at Holbergs komik på den ene side indeholder en række afgørende historiske påstande, på den anden side ikke synes at være bundet af de principper, der må gælde for historisk litteraturvidenskab. En af grundene til dette "halve" forhold til historikken synes at være tilstedeværelsen af en konkurrerende tankeform, nemlig den analogiske. Afh. er rig på analogier af yderst forskellig art, nogle er basale for undersøgelsen, andre mere kuriøse. $\mathrm{Vi}$ anfører $\mathrm{i}$ hast et par af de sidste og iler derpå videre til de første. Man møder udsagn som: "Astronomiens historie har mange lighedspunkter med en individuationsproces« (p. 384), og: »F.eks. er der jo en vis feudal struktur i den personlighedsmodel med over-jeg, jeg og drifts-jeg, som Freud opstiller for den enkelte menneskesjæls vedkommende" (p. 387). Der hævdes »en slående lighed mellem den komiske forfatter Holberg og den subtile modernistiske lyriker Rilke" (p. 377) - dog med tilføjelsen: »(sans comparaison)«. I andre tilfælde behøves hårdhændet metaforik for at få analogi-kæden til at hænge sammen, f.eks.: »Den kritik af familiens legeme og af sit eget legeme, Holberg foretager i fjerde satire, svarer til kritikken af traditionens og genrens legeme [...] (p. 156).

Ikke mindst i forbindelse med Ovids Metamorphoses tilkendegiver forfatteren en personlig sympati for den erkendelsesværdi, analogien kan indebære (f.eks. pp. 347, 355, 369). Betænkelig bliver den analogiske tænkning da også først, når den uden begrebsdefinerende tøjr slippes løs i videnskabelige sammenhænge. I Holbergs komik er den analogiske teknik nok særlig mærkbar ved benyttelsen af sekundærlitteratur. Det er en gennemgående tendens i afh., at der i en given sammenhæng bringet ét citat fra sekundærlitteraturen, hvorefter man - som et ekko af Chilian i »Ulysses« - hører et »ligeså hos Hol- 
berg «. Faren herved er, at Holberg relateres til vidt forskellige epoker og intellektuelle horisonter, ofte kun på grundlag af et punktuelt sammenfald. Sekundærlitteratur af digterisk, litteraturteoretisk eller kulturfilosofisk art står til forfatterens disposition som et synkront arsenal af formuleringer og impulser. Det er ikke mindst denne ubekymrede omgang med en broget sekundærlitteratur, der sine steder lader afh. fremstå som rigere på indfald end på sammenhæng. Mange af de flittigst benyttede skribenter er desuden selv stærkt analogiske $i$ deres tænkemåde; det gælder Emil Staiger og i eminent grad Northrop Frye ${ }^{11}$ og Francis Fergusson ${ }^{12}$.

En kort selvstændig omtale kræver afh.s benyttelse af Hegel. Den anden af de seks teser lyder: "Rakkefalgen af de varker, Holberg forfatter $i$ lobet af sin poetiske raptus, er ikke tilfaldig. Tvertimod lader der sig paivise en kunstnerisk logik $i$ det forhold, at genrene afløser hinanden $i$ rekkefolgen: komisk epos, satire, komedie, metamorfose og levnedsbeskrivelse. Afhandlingens komposition er dens hovedtese « (p. 41). Og i indledningen betones det, at denne genre-udvikling indeholder »en art kunstnerisk logik« (p. 24), »en stor konsekvens « (ibid.) og "følgerigtighed « (ibid.). Derpå forsættes: „Uden at jeg tør dække synspunktet fuldt$\mathrm{ud}$, vil jeg dog påpege, at faserne $\mathrm{i}$ dette komiske erkendelsesforløb har vigtige lighedspunkter med det paradigmatiske forløb af den græske ånds tilblivelse igennem en række genrer, som Hegel og andre har påvist» (p. 24, jvf. p. 179). Også komediens indre udvikling anskues af forfatteren som "resultat af en vækst i genrens selvrefleksion« ( $p$. 41). Selv om denne genrernes udviklingsgang ikke sker med nødvendighed, er den altså på den anden side ikke tilfældig. Og når genreudviklingen i Holbergs komedieforfatterskab ikke er tilfældig, skyldes det altså en analogi med den græske ånds genremæssige udtryk som beskrevet af Hegel o.a. Der er dog kun tale om en analogi for så vidt man læser kapitlet om poesi i Hegels $\ddot{A}$ sthetik ud fra det synspunkt, at Hegel her universaliserer den græske ånds udvikling til et totalt genresystem. En anden læsning kunne tage Hegel på ordet og se den græske ånds udvikling kun som eksemplarisk i forhold til den aprioriske lovmæssighed - og så at sige tro på udviklingen som et produkt af genrernes selvrefleksion. Men begge Hegel-benyttelser, den analogiske og den metodiske, må vel kaldes bemærkelsesværdige i et moderne litteraturvidenskabeligt arbejde?

For som sådant er disputatsen blevet betragtet $\mathrm{i}$ det foregående. Dens moment af kulturfilosofisk essay må vurderes af andre og på andre præmisser. 


\section{Noter}

1. Vilh. Andersen: Tider og Typer af dansk Aands Historie. Forste Rakke: Humanismen. Forste Del: Erasmus II, Kbh. 1909. Specielt omtalen af Peder Paars, p. 49-55, sml. Holbergs komik, pp. 74, 77 og $62 \mathrm{f}$.

2. Hans-Georg Gadamer: Wahrheit und Methode. Grundzüge einer philosophischen Hermeneutik (1960), Tübingen $1965^{2}$.

3. Fortalen til Natur- og Folke-Retten (1716); Moralske Tanker (1744), I,5; Niels Klim (1741), Potu.

4. Ludvig Holberg: Moralske Tanker, udg.: F. J. Billeskov Jansen, Kbh. 1943, pp. 41, 48.

5. Jvf. den netop udkomne monografi herom, Rich. Janko: Aristotle on Comedy: Towards a Reconstruction of Poetics II, London 1984.

6. Ludvig Holberg: Epistler, udg.: F. J. Billeskov Jansen, IV, Kbh. 1949, p. 377.

7. Ibid., VII, Kbh. 1953, p. 354.

8. Afsnit IV,5; Poul Wessners udg., Leipzig 1902, I, p. 22. Holberg kan have kandt Donats afh. om komedien fra Friedrich Lindenbrogs udbredte Terents-udg. (Frankfurt 1623), hvor den var optrykt som indledning. Denne udgave fandtes både på Universitetsbiblioteket (Bibliotheca Hoperiana, 1676, p. 48, in qvarto nr. 703) og i Chr. Reitzers bibliotek (Det kgl. Biblioteks arkiv, E 19, in qvarto nr. 5671), hvortil Holberg havde adgang. Han anskaffer sig selv udgaven på auktionen efter Chr. Danneskjold-Samsøe i 1732 (Chr. Bruun: Fortegnelse over en Del af Ludvig Holbergs Bibliothek, Kbh. 1869, p. 30).

9. Afsnit IV,2, Wessners udg. (se n. 8), p. 21.

10. Billeskov Jansens udg. (se n. 6) V, 1951, p. 186.

11. Først og fremmest Anatomy of Criticism. Four Essays (1957), N.Y. $1969^{8}$, men ogsa The Great Code. The Bible and Literature, N.Y. \& London 1982.

12. The Idea of a Theater. A Study of Ten Plays. The Art of Drama in Changing Perspective (1949), Princeton $1972^{7}$. 